\title{
Cyberknife Radiotherapy for Pituitary Adenomas: Monitoring Response Using Magnetic Resonance Imaging
}

\section{Hipofiz Adenomlarında Cyberknife Tedavisine Yanıtın Manyetik Rezonans Görüntüleme İle Değerlendirilmesi}

\author{
Ali Fırat Sarp", Mustafa Fazıl Gelal², Ali Ölmezoğlu ${ }^{3}$, Melda Apaydın², Mehmet Coşkun², Engin Uğur \\ Yardımci $^{4}$
}

\author{
${ }^{1}$ Department Of Radiology, Faculty Of Medicine, Eskisehir Osmangazi University, Eskisehir, Turkey \\ ${ }^{2}$ Department Of Radiology, Faculty Of Medicine, Izmir Katip Celebi University Ataturk Training And Research \\ Hospital, Izmir, Turkey \\ ${ }^{3}$ Department Of Radiation Oncology, Faculty Of Medicine, Celal Bayar University, Manisa, Turkey \\ ${ }^{4}$ Department Of Radiology, Van Bolge Training And Research Hospital, Van, Turkey
}

\section{ÖZET}

GİRIŞ ve AMAÇ: Cyberknife tedavisi almış hipofiz adenomlu olgularda tedaviye yanıtın MR ile değerlendirilmesi

YÖNTEM ve GEREÇLER: Bu çalışmada 2010 ile 2014 yılları arasında, hipofiz adenomu tanısıyla Cyberknife tedavisi almış hastalar retrospektif olarak değerlendirildi. Cyberknife tedavisinden en az 6 ay sonra takip MR'1 bulunan olgular çalışmaya dahil edildi. 38 hastanın (erkek/kadın=1) tedavi öncesi ve sonrası MR görüntüleri, tedaviye yanıtın değerlendirilmesi amacıyla retrospektif olarak incelendi. Tümör hacimlerindeki değişiklikler, lokal kontrol oranı, hacim değişikliğinin izlem süresi ile ilişkisi ve olası çevre beyin parankim değişiklikleri araştırıld1.

BULGULAR: Çalışmaya dahil 38 hastanın ortalama takip süresi 25 ay (dağılım, 6-51 ay) idi. Tedavi öncesi ve sonrası ortalama tümör hacimleri arasında istatistiksel olarak anlamlı bir azalma vardı (sırasıyla $4722 \mathrm{~mm} 3 \mathrm{ve}$ $3475 \mathrm{~mm} 3$ ). Otuzsekiz hastanın 2 tanesinde radyolojik progresyon, 18 tanesinde stabil hastalı, 18 tanesinde ise regresyon saptand1. Tümör lokal kontrol oranı \%94.7 olarak hesapland1. Ayrıca, stabil ve regresyon grupları arasında yapılan analizde izlem süresinin uzamasının daha anlamlı hacim düşüşüne neden olduğu görüldü. Hasta cinsiyeti, ek tıbbi tedavi, hasta yaşı, önceki ameliyatların sayısı gibi durumların tedavi sonucunu etkilemediği saptand. Hiçbir vakada çevre dokularda patolojik sinyal ortaya çıkmadi. TARTIŞMA ve SONUÇ: Cyberknife hipofiz adenomlu olgularda etkili bir tedavi yöntemidir. Bu sonuçlar Cyberknife radyoterapisinin çevre dokularda radyopatolojik değişiklik oluşturmaksızın oldukça tatmin edici lokal tümör kontrol oranları sağladığını desteklemektedir.

Anahtar Kelimeler: CyberKnife Radyocerrahisi, MRG, Hipofiz Adenomu, Stereotaktik Radyocerrahi

\begin{abstract}
INTRODUCTION: Our aim is to determine treatment response to Cyberknife based on follow-up MRI in patients with pituitary adenoma.

METHODS: We retrospectively identified the patients with pituitary adenoma treated with Cyberknife between 2010 - 2014. Patients with postreatment eligible follow-up MRI scan after at least 6 months of Cyberknife treatment were included in this study. Pre- and posttreatment MRI scans of 38 patients (male/female $=1$ ) were retrospectively analysed to evaluate tumor response. Volumetric changes of the tumors, local control rate, volumetric changes over time and signal alterations on the surrounding brain parenchyma were assessed. RESULTS: The mean follow-up time of 38 patients was 25 months (range, 6-51 months). Significant mean tumor volume reduction was found between pre- and posttreatment mean tumor volumes, which were $4722 \mathrm{~mm} 3$ and $3475 \mathrm{~mm} 3$, respectively. There were 2 cases with radiological progression, 18 cases with stable disease and 18 cases with regression. Thus, tumor local control rate was calculated as $94.7 \%$ in our study. There was also a significant follow-up time difference between stable and radiological regression groups which indicates that increased follow-up time may be related with better volume decrease. Patient gender, additional medical treatment, age, the number of previous surgeries did not affect treatment response. Lastly, there was no case with signal alteration on the surrounding brain parenchyma.
\end{abstract}


DISCUSSION and CONCLUSION: Cyberknife is a known and effective treatment method in patients with pituitary adenoma. Our results also support that Cyberknife provides excellent local tumor control without any radiological obvious side effects on surrounding tissues.

Keywords: CyberKnife Radiosurgery, MRI, Pituitary Adenoma, Stereotactic Radiosurgery.

\section{INTRODUCTION}

Pituitary adenomas (PAs) are common sellar tumors with a prevalence around $20 \%(1,2)$. PAs are clinically important due to their mass and/or hormonal effects and symptoms are often associated with these effects. According to hormonal activity status PAs can be divided into two groups: functional and non-functional. Another classification is based on maximum tumor dimension: microadenomas (smaller than $1 \mathrm{~cm}$ ) and macroadenomas (equal or greater than $1 \mathrm{~cm}$ ).

Although surgical resection is the method of choice for treatment of PAs except prolactinoma, stereotactic radiosurgery (SRS) has gained popularity in recent years. SRS can be an effective treatment for medically inoperable or recurrent - residual tumor cases. Tumor control rates with surgical treatment alone range from 50 to $90 \%$ and SRS can be a treatment option for recurrent or residual tumors $(1,2)$.

For more than fifty years, SRS techniques have been used to treat PAs. A newly developed SRS method called CyberKnife gained popularity for PA treatment in the last decades and thriving results have been published recently (3-11).

In this study, we aimed to demonstrate magnetic resonance imaging (MRI) findings of CyberKnife treatment; such as effect of the treatment on the volume of the tumor, relationship between volume difference and follow-up time, local control rate and potential signal alterations on the surrounding brain parenchyma.

\section{MATERIALS and METHODS}

This retrospective study includes 38 PAs which were treated with CyberKnife between 2010-2014 at Izmir Katip Celebi Ataturk Training and Research Hospital. The average dose given was 25,4 Gy (range, 20 - 32 Gy) in five or seven fractions.

Patient inclusion criteria were pretreatment adequate MRI scans and the presence of eligible follow-up MRI scan after at least 6 months of CyberKnife. We would like to state that there was no particular follow up schedule in our hospital due to lack of patient cooperation after CyberKnife.

Pre-treatment MRI scans, obtained for CyberKnife treatment planning, were retrospectively analysed and compared with latest routine follow-up MRI scans available in our PACS archive. MRI scans were obtained with 1,5 Tesla Signa Excite (GE, Milwaukee, WI) MRI scanner. High resolution, volumetric, postcontrast T1-weighted (BRAVO) images were obtained in addition to routine brain MRI sequences. Pre-treatment and latest follow-up MRI scans were evaluated to measure tumor volume and to note any emerging signal anomaly on brain parenchyma. We used postcontrast axial volumetric T1-weighted (BRAVO) images to measure tumor volume. These images were recruited from our PACS archive and loaded into our radiology workstation (A.W. 4.1, General Electric). On axial sections, PAs were carefully separated from surrounding tissues by manually drawn ROIs. After this manual segmentation process, tumor volumes were measured by the software. In order to standardise statistical tests and to avoid measurement mistakes, tumors smaller than $1000 \mathrm{~mm}^{3}$ were excluded from the study.

$\mathrm{We}$ assessed radiologic treatment responses as follows: radiologic progression (20\% or more volume increase), radiologic regression (20\% or more volume decrease) and stable disease (less than $20 \%$ volume difference).

Lastly, brain parenchyma, in particular parasellar structures and cerebral white-matter, was evaluated in terms of signal abnormalities. When necessary, pre- and posttreatment images were compared side by side to determine if there were any differences.

All statistical analyzes were performed using SPSS 17.0 software. All statistical tests were performed at $95 \%$ confidence interval and a $P$ value $<0.05$ was considered to indicate statistical significance. Mann Whitney-U Test was used to compare the mean of two different groups. We compared categorical variables 
using Chi-square test. Finally, Spearman correlation analysis was performed to analyse the relationship between different numeric variables.

\section{RESULTS}

The mean age of 38 patients (male/female $=1$ ) included in this study was $47.1 \pm 13.7$ years. The mean and median follow-up times were 25 and 27 months, respectively (range, 6-51 months). Among 38 patients, 3 (7.9\%) patients had prolactin-secreting, $12(31.6 \%)$ patients had non-functional and $23(60.5 \%)$ patients had growth hormone-secreting adenomas. Median number of previous surgical resection was 1 (range 0-4). Twenty-one of 38 patients were receiving medical treatment. Among these, 4 patients were under cabergolin, 11 patients were under ocreotid, 1 patient was under lantreotid, 4 patients were under cabergolin and ocreotid and 1 patient was under ocreotid - lantreotid treatments. Demographic profiles, additional medical treatment regimes and PA types of the patients can be seen in Table 1.

Pre- and post treatment mean tumor volumes were $4722 \pm 3679 \mathrm{~mm}^{3}$ and $3475 \pm 2579$ $\mathrm{mm}^{3}$ respectively, which indicated statistically significant $(\mathrm{p}<0.001)$ mean tumor volume reduction after CyberKnife treatment (Table 2).

Among 38 patients, there were 2 cases with radiologic progression $(20 \%$ or more volume increase), 18 cases with stable disease and 18 cases with radiologic regression $(20 \%$ or more volume decrease). Tumor volumes were successfully controlled in 36 of 38 patients after CyberKnife. The sum of stable and regressed tumors was assessed as local control. Therefore, the local control rate in our study was $94,7 \%$ (36/38). A comprehensive summary of the patients can be seen in Table 3. A representative case (case number 30 ) with obvious radiologic regression is available in Figure 1.

There were 18 cases with radiologic regression. Four of them were followed up shorter than 24 months and 14 of them were followed up longer than 24 months. There were 18 cases with stable disease. Twelve of them were followed up shorter than 24 months and 6 of them were followed up longer than 24 months. The relationship between volume difference and follow-up time was statistically significant $(\mathrm{p}=0.007)$ (Table 4).

The correlations between the volumetric differences and the other variables were examined. There was no significant correlation between volumetric difference and age ( $\mathrm{r}=-$ 0.195, $\mathrm{p}=0.241$ ). Similarly, there was no significant correlation between the number of previous surgical operations and volumetric difference $(0.149, \quad p=0.371)$. When the correlation between volumetric difference and follow-up time was examined, we noticed a moderate positive correlation $(\mathrm{r}=0.477$, $\mathrm{p}=0.002)$ (Table 5).

There was no significant difference in the volumetric difference between the sexes $(\mathrm{p}=0.619)$. Similarly, there was no significant difference in the volume difference between those who received additional medical treatment and those who did not $(\mathrm{p}=0.369)$ (Table 6).

Lastly, brain parenchyma, in particular parasellar structures and cerebral white-matter, was evaluated in terms of potential signal abnormalities. When necessary, pre- and posttreatment MRI scans were compared side by side. However, none of the cases showed posttreatment newly developed signal abnormalities.

Tablo 1: Demographic Profiles, Additional Treatments and Adenoma Types of the Patients

\begin{tabular}{lll}
\hline AGE (Mean, SD) & 47.1 & 13.7 \\
\hline SEX (n, \%) & & \\
MALE & 19 & 50 \\
FEMALE & 19 & 50 \\
\hline FOLLOW-UP DURATION (MONTHS) & 27 & $6-51$ \\
\hline (Median, Min.-Max.) & 1 & $0-4$ \\
\hline Previous Surgical Resections & & \\
(Median, Min-Max) & & 44.7 \\
Additional Medical Therapy (n, \%) & 17 & 10.5 \\
$\quad$ None & 4 & 28.9 \\
$\quad$ Cabergolin & 11 & 2.6 \\
$\quad$ Ocreotid & 1 & 10.5 \\
$\quad$ Lantreotid & 4 & 2.6 \\
$\quad$ Cabergolin and Ocreotid & 1 & \\
Ocreotid - lantreotid & & \\
\hline ADENOMA TYPE (n, \%) & 3 & 7.9 \\
$\quad$ Prolactin Secreting & 12 & 31.6 \\
$\quad$ Non - Functional & 23 & 60.5 \\
Growth hormone secreting &
\end{tabular}

SD: Standart Deviation, min: Minimum, max: Maximum 
Table 2: Comparison of pre- and posttreatment mean tumor volumes

\begin{tabular}{|l|clc|}
\cline { 2 - 4 } \multicolumn{1}{c|}{} & Mean $\left(\mathrm{mm}^{3}\right)$ & $\begin{array}{l}\text { Standart } \\
\text { Deviation }\end{array}$ & $\mathrm{p}^{\mathrm{a}}$ \\
\hline Pretreatment & 4722.5 & 3679.9 & \\
Posttreatment & 3475.7 & 2579.0 & $\mathbf{0 . 0 0 1}$ \\
\hline
\end{tabular}

a: Mann Whitney U Test

Table 3: A comprehensive summary of the patients

\begin{tabular}{|c|c|c|c|c|c|c|}
\hline \multirow{2}{*}{$\begin{array}{c}\text { Cas } \\
\text { e }\end{array}$} & \multirow{2}{*}{$\begin{array}{c}\text { PA } \\
\text { Typ } \\
\text { e }\end{array}$} & \multirow{2}{*}{$\begin{array}{l}\text { Age } \\
\text { and } \\
\text { Gend } \\
\text { er }\end{array}$} & \multirow{2}{*}{$\begin{array}{c}\text { Fractio } \\
\text { ns - } \\
\text { Dose } \\
\text { (Gy) }\end{array}$} & \multirow{2}{*}{$\begin{array}{c}\text { Follow } \\
\text {-up } \\
\text { (Mont } \\
\text { hs) }\end{array}$} & \multirow{2}{*}{$\begin{array}{c}\text { Pre- } \\
\text { Treatm } \\
\text { ent } \\
\text { Volume } \\
\left(\mathbf{m m}^{3}\right)\end{array}$} & \multirow{2}{*}{$\begin{array}{c}\text { Post- } \\
\text { treatm } \\
\text { ent } \\
\text { Volum } \\
\text { e } \\
\left(\mathrm{mm}^{3}\right)\end{array}$} \\
\hline & & & & & & \\
\hline 1 & GH & $30 \mathrm{~F}$ & $7-28$ & 42 & 7398 & 2888 \\
\hline 2 & GH & $47 \mathrm{~F}$ & $5-25$ & 48 & 1570 & 1379 \\
\hline 3 & GH & $32 \mathrm{M}$ & $5-25$ & 45 & 3269 & 1360 \\
\hline 4 & GH & $61 \mathrm{~F}$ & $7-28$ & 27 & 9440 & 4188 \\
\hline 5 & GH & $47 \mathrm{~F}$ & $5-25$ & 46 & 3040 & 1489 \\
\hline 6 & GH & $30 \mathrm{~F}$ & $5-25$ & 39 & 3329 & 1993 \\
\hline 7 & GH & $59 \mathrm{M}$ & $5-25$ & 24 & 5695 & 5919 \\
\hline 8 & GH & $55 \mathrm{~F}$ & $5-25$ & 42 & 2093 & 1359 \\
\hline 9 & GH & $46 \mathrm{~F}$ & $5-25$ & 39 & 3028 & 2521 \\
\hline 10 & GH & $63 \mathrm{M}$ & $5-25$ & 29 & 3766 & 3364 \\
\hline 11 & GH & $46 \mathrm{~F}$ & $5-25$ & 9 & 2748 & 3041 \\
\hline 12 & GH & $47 \mathrm{M}$ & $7-28$ & 35 & 9141 & 7937 \\
\hline 13 & GH & $47 \mathrm{E}$ & $5-25$ & 27 & 3274 & 3979 \\
\hline 14 & GH & $56 \mathrm{M}$ & $5-25$ & 14 & 2339 & 2573 \\
\hline 15 & GH & $27 \mathrm{M}$ & $5-25$ & 35 & 4765 & 2253 \\
\hline 16 & GH & $31 \mathrm{M}$ & $5-25$ & 32 & 2523 & 1511 \\
\hline 17 & GH & $33 \mathbf{F}$ & $5-25$ & 26 & 2641 & 1507 \\
\hline 18 & GH & $64 \mathrm{M}$ & $7-28$ & 31 & 4608 & 3137 \\
\hline 19 & GH & $53 \mathrm{~F}$ & $5-25$ & 19 & 1529 & 672 \\
\hline 20 & GH & $54 \mathrm{~F}$ & $5-25$ & 6 & 2800 & 3100 \\
\hline 21 & GH & $32 \mathrm{M}$ & $5-25$ & 13 & 1589 & 1491 \\
\hline 22 & GH & $39 \mathrm{M}$ & $5-25$ & 13 & 2834 & 2296 \\
\hline 23 & GH & $36 \mathrm{~F}$ & $5-25$ & 9 & 3802 & 3001 \\
\hline \multirow[t]{2}{*}{24} & PR & $37 \mathrm{~F}$ & $5-25$ & 26 & & \\
\hline & $\mathbf{L}$ & & & & 5505 & 5324 \\
\hline \multirow[t]{2}{*}{25} & PR & $63 \mathrm{M}$ & $5-23$ & 10 & & \\
\hline & $\mathbf{L}$ & & & & 9702 & 8026 \\
\hline \multirow[t]{2}{*}{26} & PR & $76 \mathrm{M}$ & $5-20$ & 8 & & \\
\hline & $\mathbf{L}$ & & & & 8636 & 9352 \\
\hline \multirow[t]{2}{*}{27} & NO & $45 \mathrm{M}$ & $5-25$ & 50 & & \\
\hline & $\begin{array}{c}\mathbf{N} \\
\text { NO }\end{array}$ & & & & 2525 & 2254 \\
\hline 28 & $\begin{array}{c}\mathbf{N O} \\
\mathbf{N}\end{array}$ & $38 \mathrm{~F}$ & $7-28$ & 40 & 17069 & 12154 \\
\hline \multirow[t]{2}{*}{29} & NO & $52 \mathrm{M}$ & $7-28$ & 33 & & \\
\hline & $\mathbf{N}$ & & & & 9121 & 5412 \\
\hline 30 & $\begin{array}{c}\text { NO } \\
\mathbf{N}\end{array}$ & $55 \mathrm{M}$ & 7 - 32 & 22 & 15962 & 7250 \\
\hline \multirow[t]{2}{*}{31} & NO & $30 \mathrm{M}$ & $5-25$ & 8 & & \\
\hline & $\mathbf{N}$ & & & & 3122 & 2638 \\
\hline \multirow[t]{2}{*}{32} & NO & $58 \mathrm{~F}$ & $5-25$ & 36 & & \\
\hline & $\mathbf{N}$ & & & & 2196 & 952 \\
\hline \multirow[t]{2}{*}{33} & NO & $31 \mathrm{~F}$ & $5-25$ & 17 & & \\
\hline & $\mathbf{N}$ & & & & 4969 & 4485 \\
\hline 34 & $\begin{array}{c}\text { NO } \\
\mathbf{N}\end{array}$ & $71 \mathrm{~F}$ & $5-25$ & 8 & 3583 & 4357 \\
\hline \multirow[t]{2}{*}{35} & NO & $23 \mathrm{~F}$ & $5-25$ & 11 & & \\
\hline & $\mathbf{N}$ & & & & 2159 & 1478 \\
\hline \multirow[t]{2}{*}{36} & NO & $44 M$ & $5-25$ & 12 & & \\
\hline & $\begin{array}{c}\mathrm{N} \\
\text { NO }\end{array}$ & $40 \mathrm{~F}$ & $5-25$ & 28 & 2326 & 1876 \\
\hline 37 & $\mathbf{N}$ & & & & 2806 & 1493 \\
\hline 38 & $\begin{array}{c}\text { NO } \\
\mathbf{N}\end{array}$ & $73 \mathrm{M}$ & $5-25$ & 10 & 2554 & 2066 \\
\hline
\end{tabular}

NON: Non-Functional, GH: Growth Hormone Secreting, PRL: Prolactin Secreting, M: Male, F: Female
Table 4: The relationship between volume difference and follow-up time

\begin{tabular}{|c|c|c|c|c|c|}
\hline & \multicolumn{2}{|c|}{ Radiologic Regression } & \multicolumn{2}{c|}{ Stable Disease } & \multirow{2}{*}{$\mathrm{p}^{\mathrm{b}}$} \\
\hline & $\mathbf{n}$ & $\mathbf{\%}$ & $\mathbf{n}$ & $\mathbf{\%}$ & \\
\hline <24Months & $\mathbf{4}$ & $\mathbf{2 2 . 2}$ & $\mathbf{1 2}$ & $\mathbf{6 6 . 7}$ & \multirow{2}{*}{$\mathbf{0 . 0 0 7}$} \\
\hline > 24Months & 14 & 77.8 & 6 & 33.3 & \\
\hline
\end{tabular}

b: Chi-Square Test

Table 5: Correlations between the volumetric differences and other variables

\begin{tabular}{|l|cc|}
\cline { 2 - 3 } \multicolumn{1}{c|}{} & \multicolumn{2}{c|}{ Volume Difference } \\
\multicolumn{1}{c|}{ Age } & $\mathbf{p}^{\mathbf{c}}$ \\
Previous Surgeries & -0.195 & 0.241 \\
Follow-up (Months) & 0.149 & 0.371 \\
\hline
\end{tabular}

c: Spearman Correlation Analysis

Table 6: Volume differences between genders and additional medical treatments

\begin{tabular}{|c|c|c|c|}
\hline & \multicolumn{3}{|c|}{ Volume Difference } \\
\hline & $\begin{array}{c}\text { Mea } \\
n\end{array}$ & $\begin{array}{l}\text { Standart } \\
\text { Deviation }\end{array}$ & $\mathrm{p}^{\mathrm{a}}$ \\
\hline Male & $\begin{array}{c}1312 \\
.4\end{array}$ & 2048.6 & 0.6 \\
\hline Female & $\begin{array}{c}1352 \\
.2\end{array}$ & 1650.4 & 19 \\
\hline $\begin{array}{l}\text { With Medical } \\
\text { Treatment }\end{array}$ & $\begin{array}{c}1814 \\
0\end{array}$ & 2415.2 & 0.3 \\
\hline $\begin{array}{l}\text { Without Medical } \\
\text { Treatment }\end{array}$ & $\begin{array}{c}942 . \\
3\end{array}$ & 1098.1 & 69 \\
\hline
\end{tabular}

a: Mann Whitney U Test

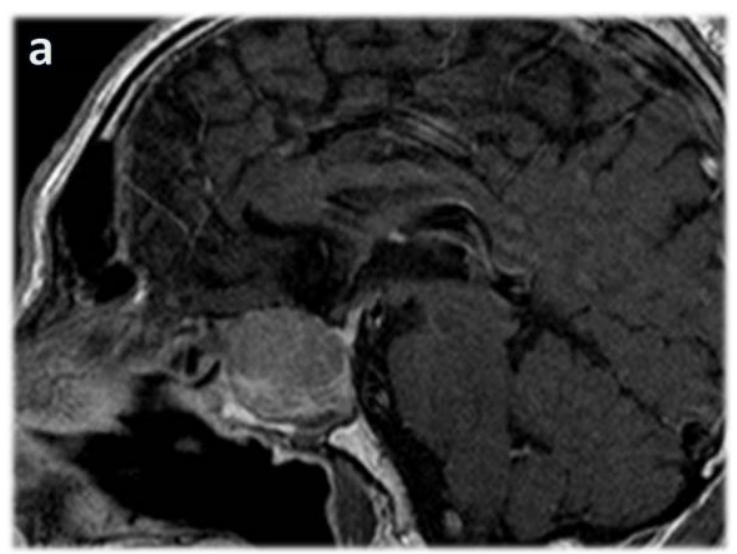

Figure 1a: A representative case (case number 30) with radiologic regression. Sagittal contrastenhanced T1 Weighted image before Cyberknife treatment. 


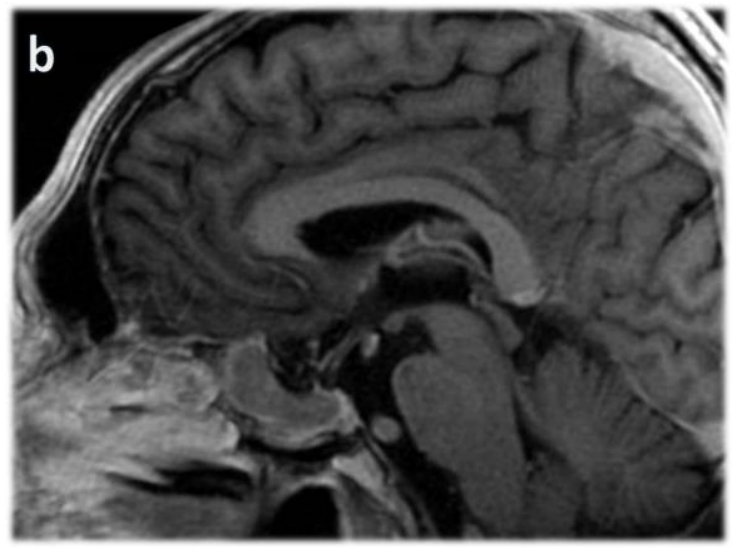

Figure 1b: Sagittal contrast-enhanced T1 Weighted image after 22 months of Cyberknife treatment.

\section{DISCUSSION}

PAs are frequent brain tumors in adults and represent approximately $10-15 \%$ of all brain neoplasms $(1,2)$. Surgical resection is the first line treatment for PAs, except prolactinoma. However, total surgical resection is usually not possible if there is extrasellar extension, dural or cavernous sinus invasion or close proximity to the surrounding critical structures. Postsurgical residual PA tissue is a potential threat for recurrence. Tumor control rates range from 50 to $90 \%$ in surgical treatment alone (1). Consequently, stereotactic radiotherapy methods have been increasingly used in cases of residual or recurrent PAs $(1,2)$. While there are numerous studies related to efficacy of other stereotactic radiosurgery methods for PAs, such as Gammaknife or LINAC, only a few studies have investigated the efficacy of CyberKnife (1,3-11).

Shortly after the introduction of CyberKnife, PA treatment with CyberKnife began. After a while treatment results and side effects published in some articles (1,3-11). In these articles, various criterias were used to determine local control. For instance, Cho et al. used the guideline proposed by the Committee of the Brain Tumor Registry of Japan, according to this guideline $25 \%$ or more growth of Gadolinium enhanced area is defined as progression (3). In the study of Iwata and colleagues, the Response Evaluation Criteria in Solid Tumors (RECIST) criteria was used to define treatment response (4). In our study we determined local control as the sum of stable (less than 20\% volume difference) and regressed (more than 20\% volume decrease) tumors according to their volumetric changes.

In the very first study about CyberKnife treatment results of PAs published by Kajiwara et al. in 2005; CyberKnife radiotherapy was applied to 21 patients with PA (5). The study group included 14 cases with non-functioning, 3 cases with prolactin-secreting, 2 cases with adrenocorticotropic hormone-secreting and 2 cases with growth hormone-secreting PAs. The follow-up time ranged from 18 to 59 months (mean $35.3 \pm 10.7$ months). Tumor size decreased in 4 patients and remained stable in 16 patients according to the guidelines of the Committee of the Brain Tumor Registry of Japan. In 1 case, cystic enlargement of PA and associated visual field loss was reported. The tumor control rate was $95.2 \%$. No other radiologically apparent side effect was reported in the study.

In a study about CyberKnife treatment for acromegaly which was published in 2007, Roberts et al. released retrospective review of 9 patients with growth hormone-secreting PA. After a mean follow-up time of 25.4 months (range, 6-53 months) no case with tumor enlargement was reported according to MRI results. In addition, there was no side effect such as stroke, secondary malignancy or brain necrosis (6).

In the study of Cho et al., 26 patients with PA, who received CyberKnife, were followed up for a mean of 30 months (range, 7 to 47 months). 17 patients had non-functioning, 3 patients with prolactin-secreting and 6 patients with growth hormone-secreting adenomas. The authors used the guidelines of the Committee of the Brain Tumor Registry of Japan and the tumor control rate in this study was $92,3 \%$. Except two patients with cystic tumor enlargement, no other radiologically detectable side effects reported (3).

In the study of Iwata and colleagues which was published in 2011; 100 non-functioning PAs were followed up between 12 and 118,5 months (mean: 33 months) after CyberKnife treatment. RECIST criteria were used to assess local control response in this study. 3- year local control rate was reported as $98 \%$. No brain necrosis or any other radiologically detectable side effects on surrounding tissues were reported. The authors concluded that CyberKnife radiotherapy with 21 Gy in 3 fractions or $25 \mathrm{~Gy}$ in 5 fractions is a safe and 
effective treatment option for non-functioning PA (4).

In the article of Chen et al. which was published in 2013; CyberKnife treatment results of 22 PAs were released. PAs treated with 25 Gy total dose in 5 sessions were followed up for a median of 30.8 months. Since there was no case with progressive disease, local control rate was found as $100 \%$ in this study (7).

Killory et al. released their CyberKnife results of 20 patients with perichiasmatic recurrent or residual PA (8). The radiologic mean follow-up time was 29.3 months (range 10.2-40.5 months). Only 1 patient was treated with $3 \times 5$ Gy and the rest of the patients were treated with $5 \times 5$ Gy in this study. They reported that none of the tumors enlarged, which indicated $100 \%$ local control.

Puataweepong et al. reported 40 perioptic PAs treated with CyberKnife (9). The median dose was 25 Gy in 5 fractions and the median follow-up period was 38.5 months (range, 1471 months). Among 40 patients, the authors reported only 1 case with radiologic tumor progression. According to this, tumor control rate could be calculated as 39/40 (97.5\%).

Avci et al. reported the outcomes of 7 patients with PA treated with CyberKnife (10). In this study median follow-up period was 18 months (range 14-55 months) and the median dose was $22 \mathrm{~Gy}$, given in 3 or 5 fractions. In this study, there was only 1 case with radiologic progression, hence local control rate in this study was $6 / 7$ (86\%).

Long-term results of 52 patients with growth hormone-secreting PAs who were treated with CyberKnife were published by Iwata et al. After a median 60 months (range 27-137 months) follow-up, Iwata et al. reported $100 \%$ 5- year local control rate. However, they reported 3 cases with local recurrence after 5 years follow-up (11).

In our study, after 27 months median follow-up; there were only 2 cases with more than $20 \%$ volume increase (case number 13 and 34). Thus, the local control rate in our study was $94.7 \%$ which is consistent with the studies mentioned above. Moreover, this local control rate is also compatible with other SRS methods, such as GammaKnife and LINAC based radiosurgery (1).

In addition, statistically significant tumor shrinkage findings were detected when the mean tumor volumes before and after CyberKnife treatments were compared in 38 patients. There were no statistically significant differences between the number of previous operations, patient age or gender and volumetric change of the tumor. However, when the relation between the volume difference and the follow-up time was examined, it was noticed that volume difference becomes statistically significant as follow-up time increases.

Like the other SRS methods, CyberKnife is very capable to concentrate radiation beams on specific target. Thus, potential side effects to surrounding tissues are minimized. In this study, no case with a side effect on surrounding tissues was detected.

As a limitation of our study, only most recent MRI scans of the patients were evaluated. Therefore, we could not assess whether there were any temporary volume increase or cystic dilatation in the PAs.

In conclusion, CyberKnife is a highly effective treatment modality for local control of PA. In addition, tumor control appears to be a time-dependent process. Brain parenchymal signal alteration should not be expected after CyberKnife treatment. Further studies with more patients and longer follow-up periods are necessary to support our results.

Conflict of interest: The authors declare that they have no conflict of interest

\section{Acknowledges}

The corresponding author would like to thank Dr. Christopher Lord for English editing of the manuscript.

\section{REFERENCES}

1- Kim W, Clelland C, Yang I, Pouratian N. Comprehensive review of stereotactic radiosurgery for medically and surgically refractory pituitary adenomas. Surg Neurol Int. 2012;3(Suppl 2) S7989. doi:10.4103/2152-7806.95419. PMID: 22826820 ; PMCID: PMC3400491.

2- Jagannathan J, Kanter AS, Sheehan JP, Jane JA, Laws ER. Benign brain tumors: sellar/parasellar tumors. Neurol Clin. 2007 Nov;25(4) 1231-49, xi. doi:10.1016/j.ncl.2007.07.003. PMID: 17964033.

3- Cho CB, Park HK, Joo WI, Chough CK, Lee KJ, Rha HK. Stereotactic Radiosurgery with the 
CyberKnife for Pituitary Adenomas. J Korean Neurosurg Soc. 2009 Mar;45(3) 157-163. doi:10.3340/jkns.2009.45.3.157. PMID: 19352477; PMCID: PMC2666117.

4- Iwata $\mathrm{H}$, Sato $\mathrm{K}$, Tatewaki $\mathrm{K}$, et al. Hypofractionated stereotactic radiotherapy with CyberKnife for nonfunctioning pituitary adenoma: high local control with low toxicity. Neuro Oncol. 2011 Aug;13(8) 916-922. doi:10.1093/neuonc/nor055. PMID: 21665918; PMCID: PMC3145469.

5- Kajiwara K, Saito K, Yoshikawa K, et al. Imageguided stereotactic radiosurgery with the CyberKnife for pituitary adenomas. Minim Invasive Neurosurg. 2005 Apr;48(2) 91-96. doi:10.1055/s-2004-830261. PMID: 15906203.

6- Roberts BK, Ouyang DL, Lad SP, et al. Efficacy and safety of CyberKnife radiosurgery for acromegaly. Pituitary. 2007;10(1) 19-25. doi:10.1007/s11102-007-0004-3. PMID: 17273921.

7- Chen YH, Chang SD, Ma HI, et al. Multisession CyberKnife radiosurgery for post-surgical residual and recurrent pituitary adenoma: preliminary result from one center. J Radiosurg SBRT. 2013;2(2) 105117. PMID: 29296349; PMCID: PMC5658882.
8- Killory BD, Kresl JJ, Wait SD, Ponce FA, Porter R, White WL. Hypofractionated CyberKnife radiosurgery for perichiasmatic pituitary adenomas: early results. Neurosurgery. 2009 Feb;64(2 Suppl) A19-25. doi:10.1227/01.neu.0000341630.42160.18. PMID: 19165069.

9- Puataweepong P, Dhanachai M, Hansasuta A, et al. The Clinical Outcome of Hypofractionated Stereotactic Radiotherapy With CyberKnife Robotic Radiosurgery for Perioptic Pituitary Adenoma. Technol Cancer Res Treat. 2016 Dec;15(6) NP10-NP15. doi:10.1177/1533034615607113. PMID: 26424501.

10- Avci GG, Guney YY, Inan GA,et al. Cyberknife ${ }^{\circledR}$ Stereotactic Radiosurgery for Pituitary Adenomas: Clinical Outcomes. Acta Oncol Tur.. 2014; 47(3): 16-19. doi: 10.5505/aot.2014.35744

11- Iwata $H$, Sato $K$, Nomura $R$, et al. Long-term results of hypfractionated stereotactic radiotherapy with CyberKnife for growth hormone-secreting pituitary adenoma: evaluation by the Cortina consensus. J Neurooncol. 2016 Jun;128(2) 267-275. doi:10.1007/s11060-016-2105-1. PMID: 26961771. 